\title{
İntraoral Bölgeye Uygulanan Girişimsel İşlemler ile İlaç Kullanımına Bağı Çenelerde Görülen Osteonekroz Arasındaki İlişki Konusunda Diş Hekimliği Öğrencilerinin Bilgi Düzeylerinin ve Farkındalığının Ölçülmesi
}

\author{
Hülya Çakır Karabaş(0000-0001-9258-053X) ${ }^{\alpha}$, Ahmet Faruk Erturk(0000-0002-4404-1547) ${ }^{\alpha}$, \\ Sevde Göksel(0000-0003-0092-7079) ${ }^{\beta}$, İlknur Özcan(0000-0001-9006-5630 ${ }^{\alpha}$
}

Selcuk Dent J, 2021; 8: 516-521(Doi: 10.15311/selcukdentj.813487)

Basvuru Tarihi: 20 Ekim 2020 Yayına Kabul Tarihi: 21 Aralık 2020

öz

İntraoral Bölgeye Uygulanan Girişimsel İşlemler ile İlaç Kullanımına Bağlı Çenelerde Görülen Osteonekroz Arasındaki İlişki Konusunda Diş Hekimliği Öğrencilerinin Bilgi Düzeylerinin ve Farkındalığının Ölıcülmesi

Amaç: Osteonekrozun ilaçlarla ilișkili olabileceği kavramı, ilk kez 2003 yılında tanımlanmıştır. Multipl miyelom, kemik metastazları, osteoporoz ve Paget hastalığı gibi birçok hastalığın tedavisinde kullanılan bisfosfonatlar, kemik rezorpsiyonunu inhibe eder. Bisfosfonat gibi antirezorptif ilaçlarla tedavi edilen hastalarda oral kontroller ve tedaviler önemli olup tıp ve diş hekimlerinin söz konusu hastalarda dental risk faktörlerinin değerlendirilmesi konusunda iş birliği sağlamaları gerekmektedir. Çalışmamızın amacı, diş hekimliği öğrencilerinin ilaç kullanımına bağı osteonekroz hakkındaki bilgi düzeyleri ve farkındalığını ölçmektir.

Gereç ve Yöntemler: Çalışmamıza üniversitemizin diş hekimliği fakültesinde eğitim gören 4. ve 5. sınıf öğrencilerinden toplam 188 kişi dahil edilmiştir. Anket soruları, demografik bilgiler (yaş ve cinsiyet vb.), bisfosfonat ve osteonekroz ile ilgili bilgiler (ilacın kullanıldığı hastalıklar, osteonekroza neden olabilecek diğer ilaçlar vb.) ve örnek vaka üzerinden osteonekroz hastalarına ve bu hastalardaki dental tedavi yaklaşıma ilişkin sorulardan oluşmaktadır. Alınan cevaplar istatistiksel olarak değerlendirilmiştir.

Bulgular: Ankete yaş ortalamaları $21,96 \pm 0,995$ olan 4 .sınıflardan 114 öğrenci(81 kadın (\%71.10); 33 erkek (\%28.90)) ve yaş ortalamaları $22,99 \pm 0,972$ olan 5. sınıflardan 74 öğrenci ( 51 kadın (\%68.90); 23 erkek (\%31.10)) olmak üzere toplam 188 öğrenci dahil olmuştur.

Sonuç: Çalışmamızdan elde ettiğimiz bulgulara dayanarak verilen eğitimin müfredatlarında bu konuyla ilgili güncellemelerin yapılması önerilmektedir.

\section{ANAHTAR KELIMELER}

Çenenin bifosfonat ilişkili osteonekrozu, Eğitim diş hekimliği lisans, Osteonekroz

Osteonekrozun ilaçlarla ilişkili olabileceği kavramı, Marx tarafından ilk kez 2003 yılında tanımlanmıştır. ${ }^{1-4}$ 2009 yilında, Amerikan Oral ve Maksillofasiyal Cerrahi Derneği (AAOMS) tarafından, daha önce baş-boyun bölgesinden radyoterapi almamış, bisfosfonat kullanmış ya da kullanmakta olan hastaların çenelerinde 8 haftadan uzun süre mukozadan açığa

\section{ABSTRACT}

Measuring the Knowledge Level and Awareness of Dentistry Students on the Relationship Between Interventional Procedures Applied to the Intraoral Region and Osteonecrosis in the Jaws Due to Medication Use

Background: The concept that osteonecrosis may be associated with drugs was first defined in 2003. Bisphosphonates used in the treatment of many diseases such as multiple myeloma, bone metastases, osteoporosis and Paget's disease inhibit bone resorption. Oral controls and treatments are important in patients treated with antiresorptive drugs such as bisphosphonates, and medical and dentists need to cooperate in evaluating dental risk factors in these patients. The aim of our study is to measure the knowledge and awareness of dentistry students about drug-induced osteonecrosis.

Methods: A total of 188 students from 4th and 5th grade studying at the Faculty of Dentistry of our university were included in our study. Questionnaire questions consist of demographic information (age and gender, etc.), information about bisphosphonates and osteonecrosis (diseases where the drug is used, other drugs that may cause osteonecrosis, etc.) and questions about osteonecrosis patients and the dental treatment approach in these patients. The answers received were evaluated statistically.

Results: Based on the findings of our study, it is recommended to update the curricula of the education provided on this subject.

Conclusion: There was no difference in adhesive bonding strength between adhesive systems; conventional incremental composite was found to be more successful than Bulk-fill composites.

\section{KEYWORDS}

Bisphosphonate-Associated Osteonecrosis of the Jaw, Education Dental Graduate, Osteonecrosis

çıkan kemik görüntüsü, bisfosfonata bağlı çene kemiği osteonekrozu (BRONJ) olarak tanımlanmış ve 4 evrede değerlendirilmiştir. ${ }^{5-7}$

Çene osteonekrozu, denosumab alan kişilerde de görülmeye başlandıktan sonra Amerikan Diş Hekimleri Birliği, Bilimsel İşler Konseyi, Antiresorptif Ajanlar Uzman Komitesi, antirezorptif ajanlara bağlı

\footnotetext{
${ }^{\alpha}$ İstanbul Üniversitesi Diş Hekimliği Fakültesi Ağız, Diş ve Çene Radyolojisi AD. İstanbul, Türkiye

${ }^{\beta}$ Ankara Medipol Üniversitesi Diş Hekimliği Fakültesi Ağız, Diş ve Çene Radyolojisi AD. Ankara, Türkiye
} 
çene kemiği osteonekrozu (ARONJ) olarak adlandırılan yeni isimlendirme için öneride bulunmuştur. ${ }^{8} 2014$ yılında ise sadece bisfosfonatların değil aynı zamanda yeni çıkan kemoterapi ilaçlarının da aynı etkiyi göstermeleri nedeniyle durum güncellemesi gerekliliği ortaya çıkmıştır. AAOMS, bisfosfanata bağlı çene osteonekrozunun (BRONJ) terimi ve antirezorptif ajan kaynaklı osteonekroz (ARONJ) terimi yerine; ilaca bağlı çene kemiği osteonekrozu (MRONJ) teriminin kullanılmasını önermiştir. ${ }^{9-11} \quad \mathrm{Bu}$ değişim; antirezorptif ve antianjiogenik ilaç tedavisiyle ilişkili maksilla ve mandibulayı içeren osteonekroz olgularının artan sayısı ile desteklenmektedir. ${ }^{12}$

Bu tanımına göre hastalar;

-Antirezorptif veya antianjiogenik ajanlarla tedavi görmüş ya da görmekte olmaları,

- Maksillofasiyal bölgede 8 haftadan fazla süren intraoral veya ekstraoral sondalanabilir fistülü olan kemik veya ekspoze kemik durumuna sahip olmaları,

- Çenede radyoterapi geçmişine ya da metastatik hastalığa sahip olmamaları, durumlarının tamamına içeriyorlar ise MRONJ olarak kabul edilebilirler.

Risk faktörleriyle ilişkili olarak MRONJ insidansı \%15 den az olarak rapor edilmiştir. ${ }^{13}$ MRONJ ile ilişkili olduğu bilinen ilaçlar arasında bisfosfonatlar (oral ve IV), denosumab gibi RANK-L inhibitörleri ve tirozinkinaz inhibitörleri ve hümanizemonoklonal antikorlar gibi antianjiyogenik ilaçlar bulunur. ${ }^{13}$

İntravenöz bisfosfanatlar, kemiğin solid tümör metastazları, kanserle ilişkili hiperkalsemi, Paget hastalığı ve Multipl miyelom gibi durumlarda kullanılmaktadır. ${ }^{14}$ MRONJ'un tedavisi klinisyenler için zordur. $^{3} \mathrm{Bu}$ nedenle MRONJ'u önlemek için antirezorptif ilaçlarla tedavi edilen hastalarda tedavi öncesi ve tedavi boyunca yapılacak düzenli orodental kontroller gereklidir. ${ }^{3}$ Bunu sağlamak amacıyla, geleceğin diş hekimleri olacak fakültemizdeki öğrencilerin bilgi düzeyleri ve farkındalığının ölçülüp eksik kaldıkları noktalar tespit edilerek ileride meslek hayatlarında karşılaşabilecekleri olası osteonekroz vakalarını olabildiğince azaltmaya çalışmak amaçlanmaktadır.

\section{GEREÇ VE YÖNTEMLER}

Çalışmaya katılacak gönüllü sayısı, fakültemiz 4. ve 5. sınıflarında eğitim gören toplam öğrenci sayıları $(\mathrm{N}=402)$ ve referans kaynaklar dikkate alınarak \%95 güven ve \%80 güç ile yapılan güç analizi sonucu minimum 176 olarak bulunmuştur. Çalışmamıza İstanbul Üniversitesi Diş Hekimliği Fakültesinde eğitim gören 4. ve 5. sınıf öğrencilerinden toplam 188 kişi katılmıştır. Çalışmamıza sadece 4. ve 5. sınıf öğrencileri dâhil edilmiştir. Gönüllülerin elektronik ortamda çalışmaya katılması sağlanmıştır. Gönüllü katılım formu anketin yayınlandığı web sitesi üzerinden katılımcıların erişimine sunulmuş ve katılımcılar gönüllü olur formunu elektronik olarak onayladıktan sonra anket sorularına erişebilmişlerdir. Çalışmada kişisel bilgiler istenmemiştir. Gönüllüler her soruyu tek tek cevapladıktan sonra ankette ilerleyebilmiş önceki sorularla korelasyon kurularak objektif olmayan yanıtların verilmesini önlemek amacıyla gönüllülerin geriye dönerek eski soruları görmeleri kısıtlanmıştır. Anket soruları, demografik bilgiler (yaş, cinsiyet vb.), bisfosfonat ve osteonekroz ile ilgili bilgiler (ilacın tedavisinde kullanıldığı hastalıklar, osteonekroza neden olabilecek diğer ilaçlar vb.) ve bir örnek vaka ile osteonekroz hastalarına ve bu hastalardaki dental tedavi yaklaşıma ilişkin sorulardan oluşmaktadır. İstanbul Üniversitesi Diş Hekimliği Fakültesi Klinik Araştırmalar Etik Kurulunun 18/07/2018 tarih ve 311 sayılı onayıyla yürütülen bu çalışma Helsinki Deklerasyonu 2008 prensiplerine uygun olarak yapılmıştır.

Çalışmamızdaki analizler için Statistical Package for the Social Sciences (IBM SPSS, USA V21) kullanılmıştır. Kategorik değişkenler arasında yapılacak değerlendirmelerde gruplar arasında fark bakılması için Ki-Kare testi kullanılmıştır. Uygulanan anket sonucunda toplanan demografik ve klinik verilerin sürekli olanları için ortalama, standart sapma, minimum ve maksimum değerleri verilerek tanımlayıcı istatistikler belirtilmiştir. Cinsiyet gibi kategorik değişkenlerin frekans dağılımları ve yüzdeleri belirtilmiştir.

\section{BULGULAR}

Ankete yaş ortalamaları 21,96 $\pm 0,995$ olan 4.sınıflardan 114 öğrenci(81 kadın (\%71.10); 33 erkek (\%28.90)) ve yaş ortalamaları $22,99 \pm 0,972$ olan 5.sınıflardan 74 öğrenci (51 kadın (\%68.90); 23 erkek (\%31.10)) olmak üzere toplam 188 öğrenci dahil olmuştur. Öğrencilerin bisfosfonatların kullanıldığı hastalıklar, etken maddeleri ve verilen örnek bir vakada tedavi seçenekleri için verdiği yanıtlar Tablo 1'de görülmektedir. 
Tablo 1.

Anket soru ve cevaplarının sınıflara göre dağılımı.

\begin{tabular}{|c|c|c|c|c|}
\hline & & 4.Sinif & 5.Sinff & \\
\hline \multirow{8}{*}{$\begin{array}{l}\text { Hangi hastalıkların } \\
\text { tedavisinde } \\
\text { bisfosfonat } \\
\text { kullanilır? }\end{array}$} & Kansere Bağlı Hiperkalsemi & $58(\% 50.90)$ & $27(\% 36.50)$ & $p=(0.000)$ \\
\hline & $\begin{array}{l}\text { Kemiğe Solid Tümör } \\
\text { Metastazları }\end{array}$ & $61(\% 53.50)$ & $48(\% 64.90)$ & \\
\hline & Paget Hastalığı & $63(\% 55.30)$ & $42(\% 56.80)$ & \\
\hline & Multiple Miyelom & $65(\% 57.00)$ & $29(\% 39.20)$ & \\
\hline & FibrözDisplazi & $47(\% 41.20)$ & $14(\% 18.90)$ & \\
\hline & Osteogenezis Imperfekta & $40(\% 35.10)$ & $11(14.90)$ & \\
\hline & Osteoporoz & $100(\% 87.70)$ & $71(\% 95.90)$ & \\
\hline & Multipl Skleroz & $14(\% 12.30)$ & $8(\% 10.80)$ & \\
\hline \multirow{11}{*}{$\begin{array}{c}\text { Hangi etken } \\
\text { maddeler } \\
\text { osteonekroza } \\
\text { neden olabilir? }\end{array}$} & Asebutolol & $7(\% 6.10)$ & $2(\% 2.70)$ & $p=(0.006)$ \\
\hline & Sunitinib & $11(\% 9.60)$ & $5(\% 6.80)$ & \\
\hline & Everolimus & $7(\% 6.10)$ & $2(\% 2.70)$ & \\
\hline & Flufenazindeconat & $14(\% 12.30)$ & $6(\% 8.10)$ & \\
\hline & Alendronat & $77(\% 67.50)$ & $62(\% 83.80)$ & \\
\hline & Riociguat & $5(\% 4.40)$ & $3(\% 4.10)$ & \\
\hline & Pamidronat & $39(\% 34.20)$ & $42(\% 56.80)$ & \\
\hline & Zoledronat & $74(\% 64.90)$ & $60(\% 81.10)$ & \\
\hline & Denosumab & $20(\% 17.50)$ & $10(\% 13.50)$ & \\
\hline & Bromokriptin & $5(\% 4.40)$ & $3(\% 4.10)$ & \\
\hline & Bevacizumab & $11(\% 9.60)$ & $4(\% 5.40)$ & \\
\hline \multirow{13}{*}{$\begin{array}{l}\text { Hangisinin uzun } \\
\text { süre kullanımı } \\
\text { osteonekroza } \\
\text { neden olabilir? }\end{array}$} & Antirezorptif Ilaçlar & $69(\% 60.50)$ & $34(\% 45.90)$ & $\mathrm{p}=(0.029)$ \\
\hline & Bisfosfonatlar & $110(\% 96.50)$ & $74(\% 100)$ & \\
\hline & Antidiabetik ilaçlar & $0(\% 0.00)$ & $2(\% 2.70)$ & \\
\hline & Antihipertansif ilaçlar & $1(\% 0.90)$ & $1(\% 1.40)$ & \\
\hline & Kortikosteroidler & $55(\% 48.20)$ & $28(\% 37.80)$ & \\
\hline & Antibiyotikler & $2(\% 1.80)$ & $0(\% 0.00)$ & \\
\hline & $\begin{array}{l}\text { Non-steroidAntienflamatuar } \\
\text { ilaçlar }\end{array}$ & $2(\% 1.80)$ & $1(\% 1.40)$ & \\
\hline & Antidiüretik Ilaçlar & $4(\% 3.50)$ & $0(\% 0.00)$ & \\
\hline & Oral Kontraseptifler & $9(\% 7.90)$ & $1(\% 1.40)$ & \\
\hline & Antidepresanlar & $2(\% 1.80)$ & $0(\% 0.00)$ & \\
\hline & Kemoterapötik ilaçlar & $52(\% 45.60)$ & $37(\% 50.00)$ & \\
\hline & $\begin{array}{l}\text { Antikoagülan/Antiagregan } \\
\text { illaçlar }\end{array}$ & $3(\% 2.60)$ & $2(\% 2.70)$ & \\
\hline & Diğer & $0(\% 0.00)$ & $2(\% 2.70)$ & \\
\hline
\end{tabular}

\begin{tabular}{|c|c|c|c|c|}
\hline & & 4.Sinif & 5.Sinif & \\
\hline \multirow{2}{*}{ 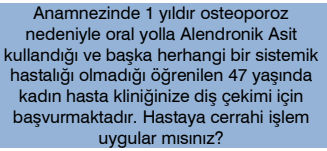 } & Evet & $\begin{array}{l}25 \\
(\% 21.90)\end{array}$ & $\begin{array}{l}9 \\
(\% 12.90)\end{array}$ & $\begin{array}{l}\text { ns } \\
(p=0.089)\end{array}$ \\
\hline & Hayir & $\begin{array}{l}89 \\
(\% 78.10)\end{array}$ & $\begin{array}{l}65 \\
(\% 87.80)\end{array}$ & \\
\hline \multirow{2}{*}{$\begin{array}{l}\text { Bisfosfonatlar hakkında bilgi sahibi } \\
\text { misiniz? }\end{array}$} & Evet & $\begin{array}{l}111 \\
(\% 97.40)\end{array}$ & $\begin{array}{l}71 \\
(\% 95.90)\end{array}$ & $\begin{array}{l}\text { ns } \\
(p=0.588)\end{array}$ \\
\hline & Hayır & $3(\% 2.60)$ & $3(\% 4.10)$ & \\
\hline \multirow{2}{*}{$\begin{array}{l}\text { Osteonekroz hakkında bilgi sahibi } \\
\text { misiniz? }\end{array}$} & Evet & $\begin{array}{l}107 \\
(\% 93.90)\end{array}$ & $\begin{array}{l}71 \\
(\% 95.90)\end{array}$ & $\begin{array}{l}\text { ns } \\
(p=0.533)\end{array}$ \\
\hline & Hayir & $7(\% 6.10)$ & $3(\% 4.10)$ & \\
\hline \multirow{2}{*}{$\begin{array}{l}\text { Eğer cerrahi isslem uygularsanız ek bir } \\
\text { prosedür uygular mısinız? }\end{array}$} & Evet & $\begin{array}{l}22 \\
(\% 88.00)\end{array}$ & $\begin{array}{l}8 \\
(\% 88.90)\end{array}$ & $\mathrm{p}=(0.005)$ \\
\hline & Hayir & $3(\% 12.00)$ & $\begin{array}{l}1 \\
(\% 11.10)\end{array}$ & \\
\hline \multirow{5}{*}{ Ek Prosedürler } & $\begin{array}{l}\text { Isslem Öncesi } \\
\text { AntbiyotikProfilaksisi }\end{array}$ & $6(\% 27.30)$ & $\begin{array}{l}4 \\
(\% 50.00)\end{array}$ & $\begin{array}{l}\mathrm{ns} \\
\mathrm{p}=(0.195)\end{array}$ \\
\hline & $\begin{array}{l}\text { İslem Sonrası } \\
\text { Antibiyotik } \\
\text { Profilaksisi }\end{array}$ & $5(\% 22.70)$ & $\begin{array}{l}2 \\
(\% 25.00)\end{array}$ & \\
\hline & $\begin{array}{l}\text { Illaç Kullanımııı } \\
\text { Başlatan Hekimi ile } \\
\text { Konsültasyon }\end{array}$ & $\begin{array}{l}20 \\
(\% 90.90)\end{array}$ & $\begin{array}{l}5 \\
(\% 62.50)\end{array}$ & \\
\hline & $\begin{array}{l}\text { Isslem Öncesinde } \\
\text { Serum CTX Değerini } \\
\text { Kontrol Etme }\end{array}$ & $\begin{array}{l}20 \\
(\% 90.90)\end{array}$ & $\begin{array}{l}6 \\
(\% 75.00)\end{array}$ & \\
\hline & Diğer & $2(\% 9.10)$ & $\begin{array}{l}2 \\
(\% 25.00)\end{array}$ & \\
\hline \multirow{4}{*}{$\begin{array}{l}\text { Yapacağınız cerrahi isslemde ostenekroz } \\
\text { riskini ekarte edebilmek iciin sizce serum } \\
\text { CTX değeri hangi sinırlarda olmalidir? }\end{array}$} & $<100 \mathrm{pg} / \mathrm{ml}$ & $3(\% 15.00)$ & $\begin{array}{l}3 \\
(\% 50.00)\end{array}$ & $\begin{array}{l}\mathrm{ns} \\
\mathrm{p}=(0.266)\end{array}$ \\
\hline & $100-125 \mathrm{pg} / \mathrm{ml}$ & $7(\% 35.00)$ & $\begin{array}{l}2 \\
(\% 33.30)\end{array}$ & \\
\hline & $126-149 \mathrm{pg} / \mathrm{ml}$ & $4(\% 20.00)$ & $0(\% 0.00)$ & \\
\hline & $>149 \mathrm{pg} / \mathrm{ml}$ & $6(\% 30.00)$ & $\begin{array}{l}1 \\
(\% 16.70)\end{array}$ & \\
\hline
\end{tabular}


"Hangi hastalıkların tedavisinde bisfosfonat kullanılır?" sorusuna çalışmaya katılan 4. sınıf öğrencilerin \%87.70'i, 5. sınıfların \%95.90'ı osteoporoz yanıtını verirken, Multipl Skleroz yanıtı veren öğrenci oranı 4. sınıflarda \%12.30, 5. sınıflarda \%10.80 olarak görülmüştür(Şekil 1).

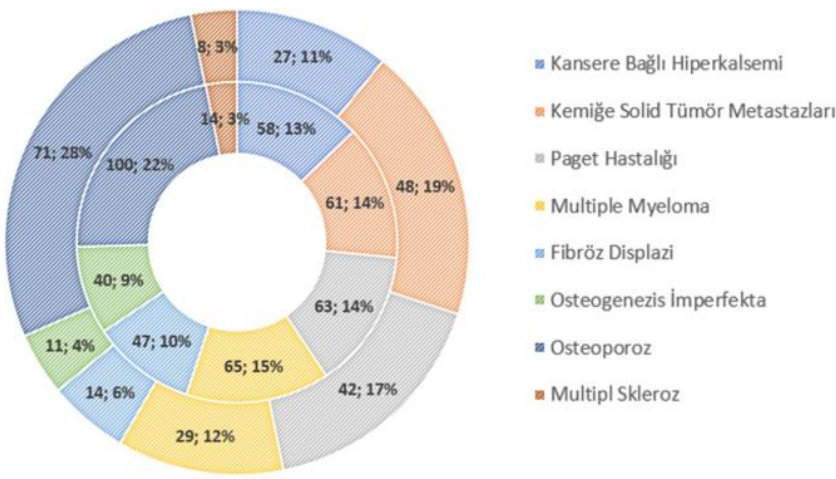

Şekil 1

"Hangi hastalıkların tedavisinde bisfosfonat kullanılı?" sorusuna verilen yanıtlar( $\mathrm{p}=0.000)$. (İç halka 4.sınıf öğrencilerini, dış halka ise 5.sınıf öğrencilerini temsil etmektedir.)

Bu soruya iki sınıfında verdiği diğer yanıtlar da incelendiğinde iki grup arasında istatistiksel olarak anlamlı derecede fark görülmüştür $(p=0.000)$. "Hangi etken maddeler osteonekroza neden olabilir?" sorusuna 4. sınıflar \%67.50 oranında Alendronat yanıtı, \%64.90 oranında Zolendronat yanıtı verirken 5 . sınıfların \%83.80'i Alendronat ve \%81.10'u Zoledronat yanıtı vermişlerdir. Bu soruya en düşük oranda 4. sınıfların \%4.40'ı eşit oranlarda Riociguat ve Bromokriptin yanıtı verirken 5. sınıfların \%2.70'i eşit oranlarda Asebutolol ve Everolimus yanıtını vermişlerdir(Şekil 2).
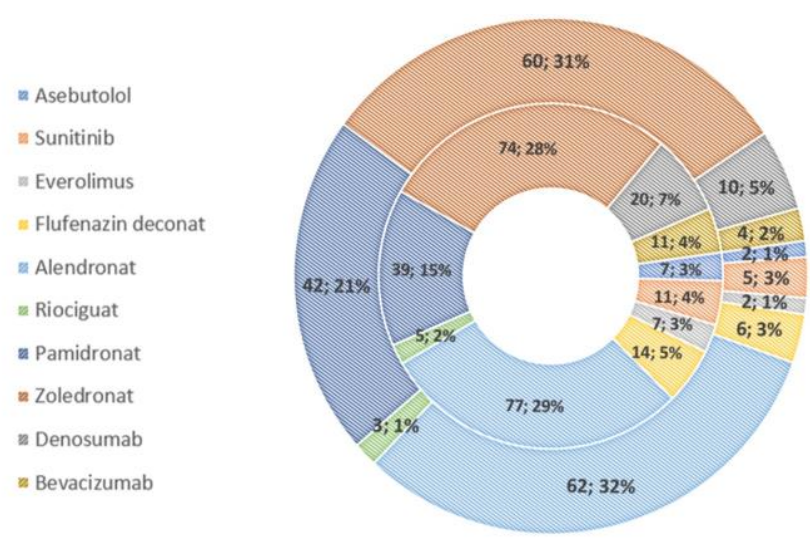

Şekil 2

"Hangi etken maddeler osteonekroza neden olabilir?" sorusuna verilen yanıtlar $(\mathrm{p}=0.006)$. (İç halka 4.sınıf öğrencilerini, dış halka ise 5.sınıf ögrencilerini temsil etmektedir.)

Diğer verilen yanıtlarda değerlendirildiğinde iki sınıf arasında istatistiksel olarak anlamlı derecede fark izlenmiştir $(p=0.006)$. "Hangisinin uzun süre kullanımı osteonekroza neden olabilir?" sorusuna en yüksek oranlarda 4.sınıflardan Bisfosfonatlar(\%96.50) ve Antirezorptif(\%60.50) ilaçlar yanıtı verilirken 5.sınıf öğrencilerinin Bisfosfonatlar(\%100) ve Kemoterapötik İlaçlar(\%50.00) yanıtını verdiği görülmektedir(Şekil 3).

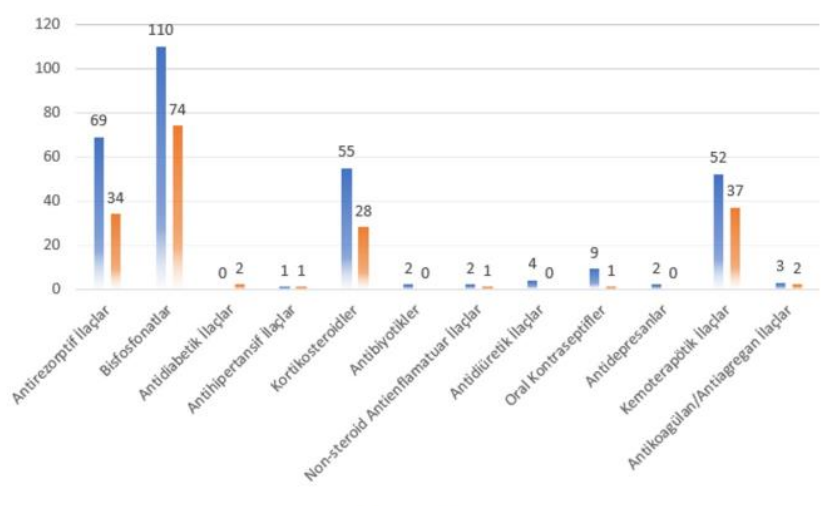

Şekil 3
"Hangisinin uzun süre kullanımı osteonekroza neden olabilir?” sorusuna
verilen yanıtlar $(\mathrm{p}=0.029)$.

Bu soru için iki sınıf arasında istatistiksel olarak anlamlı derecede fark görülmüştür $(p=0.029)$. Anketimizde verilen örnek bir vaka sorusuna 4. sınıfların \%21.90'ı, 5.sınıfların \%12.90'ı "evet" yanıtını verirken 4. sınıfların \%78.10'u ve 5. sınıfların \%87.80'i "hayır" yanıtını vermişlerdir. İki grup arasında istatistiksel olarak anlamlı bir ilişki izlenememiştir $(p=0.089)$. Bu soruya "evet" yanıtını veren toplam 34 öğrenciye cerrahi işlem uygulamalarında ek bir prosedür uygulamaları yönünde sorulan soruya 4. sınıfların \%88.00'i, 5. sınıfların \%88.90'ı "evet” yanıtını verirken 4. sınıfların \%12.00'si ve 5. sınıfların \%11.10'u "hayır" yanıtını vermişlerdir. İki sınıf arasında istatistiksel olarak anlamlı bir ilişki görülmüştür $(p=0.005)$. Ek prosedür uygulayacağını belirten toplam 30 öğrenciye hangi prosedürleri uygulayacakları sorulduğunda, 4.sınıfların \%90.90'ı eşit oranda hastanın ilaç kullanımını başlatan hekimiyle konsültasyon ile Serum CTX değerlerini işlem öncesinde kontrol etme yanıtlarını verirken, 5. sınıfların \%75.00'i işlem öncesinde Serum CTX değerlerini kontrol ederim yanıtını, \%62.50'si ise hastanın ilaç kullanımını başlatan hekimiyle konsültasyon yanıtını vermişlerdir(Şekil 4).

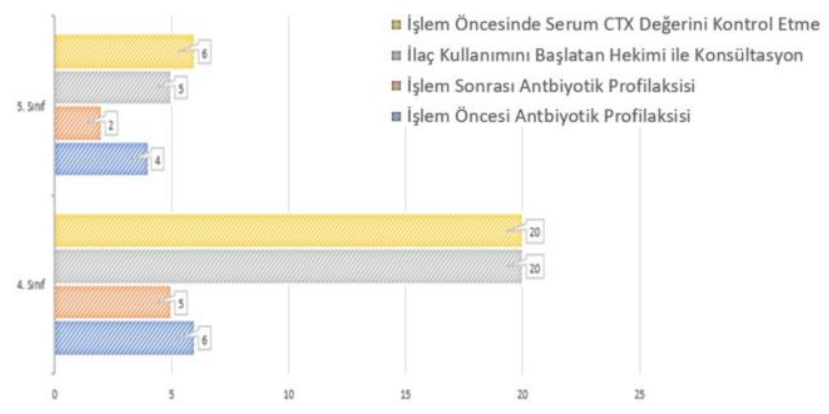

Şekil 4

"Eğer cerrahi işlem uygularsanız hangi ek prosedüreri uygularsınız?" sorusuna verilen yanitlar $(\mathrm{p}=0.195)$. 
İki sınıf arasında bu soru için istatistiksel olarak anlamlı bir ilişki görülememiştir $(p=0.195)$. İşlem öncesinde Serum CTX değerlerini kontrol ederim yanıtını veren toplam 26 öğrenciye "Yapacağınız cerrahi işlemde osteonekroz riskini ekarte edebilmek için sizce serum CTX değeri hangi sınırlarda olmalıdır?" sorusu yöneltildiğinde, 4. sınıfların \%35.00'i 100-125 pg/ml yanıtını verirken, 5. sınıfların $\% 50 \mathrm{si}<100 \mathrm{pg} / \mathrm{ml}$ yanıtını vermişlerdir. Bu soruda iki grup arasında istatistiksel olarak anlamlı bir fark görülmemiştir $(p=0.266)$.

\section{TARTIŞMA}

Multipl miyelom, kemik metastazları, osteoporoz ve Paget hastalığı gibi birçok hastalığın tedavisinde kullanılan bisfosfonatlar kemik rezorpsiyonunu inhibe eder. ${ }^{15-17} \mathrm{Bu}$ yüzden tıp ve diş hekimlerinin bisfosfonat kullanan hastalarda dental risk faktörlerinin değerlendirilmesi konusunda işbirliği sağlamaları önemlidir. ${ }^{18} \mathrm{Bu}$ konuda literatürde diş hekimliği öğrencilerinin bilgi düzeylerini ölçen ilk çalışmalar 2010 yılında bildirilmiştir. ${ }^{19,20}$ Biz de çalışmamızda üniversitemizde eğitim gören 4 . ve 5.sınıf öğrencilerinin bu konudaki bilgi düzeylerinin ve farkındalıklarını ölçmeyi amaçladık.

Öğrencilere bisfosfonatların kullanıldığı hastalıklar sorulduğunda Rosella ve ark. ${ }^{3}$ çalışmalarında bu soruya yüksek oranda osteoporoz yanıtı verildiği görülmüştür. Bizim çalışmamızda da 4. ve 5.sınıflarda yüksek oranda, Rosella ve ark. ${ }^{3}$ çalışmasında ki bulgular örtüşecek şekilde, doğru yanıt olan osteoporoz (\%87.70;\%95.90) yanıtı verilmiştir. Bisfosfonat tedavileri için temel endikasyonlar arasında osteoporoz görüldüğünden11,21 öğrencilerin osteoporoz hakkında daha çok bilgi sahibi olduğu söylenilebilir. Bununla birlikte 4 . ve 5.sınıflardaki öğrenciler düşük oranda da olsa (\%12.30;\%10.80) Multipl Skleroz işaretlemişlerdir ki bu yanlış yanıttır. Aralarında anlamlı bir fark izlenen bu her iki sınıftan 5.sınıf öğrencilerin yüksek oranda doğru yanıt ve düşük oranda yanlış yanıt veriyor olmaları, bize gördükleri eğitimin bu konu ile ilgili olumlu etkilerinin olduğunu göstermektedir. Öğrencilere osteonekroza neden olabilecek etken maddeler sorulduğunda Rosella ve ark. $^{3}$ ile López-Jorner ve ark. ${ }^{15}$ çalışmalarında bu soruya yüksek oranda Alendronat ve Zolendronate yanıtı verildiği görülmüştür. Bizim çalışmamızda da 4. ve 5. sınıflarda yüksek oranda, Rosella ve ark. $^{3}$ ile López-Jorner ve ark. ${ }^{15}$ çalışmasındaki bulgularla örtüşecek şekilde, doğru yanit olan Alendronat (\%67.50;\%83.80) ve Zolendronate (\%64.90;\%81.80) yanıtları verilmiştir. Bu sonuç bize osteonekroz vakalarında en sık Alendronate ve Zolendronate etken maddeleri kullanıldığından ${ }^{22}$, öğrenciler tarafından daha iyi bilindiğini göstermektedir. Verilen örnek vakada cerrahi işlem uygulama konusunda görüşleri istenen 4. ve 5.sınıf öğrencilerden yüksek oranda hayır (\%78.10;\%87.80) yanıtı alınırken düşük oranda evet
(\%21.90;\%12.90) yanıtı alındığı görülmektedir. Bizim çalışmamızdaki bulgularımızla örtüşecek şekilde Tanna ve ark..$^{14}$ çalışmasında da benzer soruya yüksek oranda hayır (\%58) ve düşük oranda evet (\%42) yanıtı verildiği görülmüştür. Bu sonuçlar öğrencilerin, osteonekroz riski bulunan hastalara yönelik yaklaşımlarında daha dikkatli olabileceğini göstermektedir. Yine örnek vaka için cerrahi işlem uygulayacağını belirten 34 öğrencinin, cerrahi işlem uygulamadan önce ek prosedürlere başvurmaları konusundaki görüşleri alındığında, 4 . ve 5. sınıf öğrencilerin yüksek oranda (\%88.00; \%88.90) "evet" yanıtı verdiği görülmektedir. Uygulayacakları ek prosedürler sorulduğunda ise 4 . ve 5. sınıf öğrencilerinden yüksek oranda ilaç kullanımını başlatan hekimi ile konsültasyon (\%90.90;\%62.50) ve işlem öncesi serum CTX değerlerini kontrol etme (\%90.90;\%75.00) yanıtları alınmıştır. Tanna ve ark. ${ }^{14}$ çalışmasında da benzer soruya yüksek oranda (\%83) işlem öncesi ve sonrası antibiyotik tedavisi önerdikleri görülmektedir.

\section{SONUÇ}

Her ne kadar elde ettiğimiz bulgularda yüksek oranda doğru yanıtlara ulaşmış olsak ta düşük oranda verilen hatalı yanıtlarda olduğu görülmüştür. Bu durum bize halen diş hekimliği eğitiminin çalışmamıza katılan gönüllüler üzerinde, osteonekroz riski bulunan hastaların dental tedavileri ve bisfosfonatlar ile osteonekroz neden olma potansiyeline sahip olan diğer ilaçların farkındalığını artırma konusunda henüz yeterli olmadığını göstermektedir. Çalışmamızdan elde ettiğimiz bulgulara dayanarak diş hekimliğinden mezun hekimlerimizin osteonekroz vakalarıyla karşılaşmamaları adına osteonekroza neden olabilecek ilaç tedavisine başlamayı planlayan hekimlerle konsülte ve koordine şekilde hareket ederek hem kendileri için hem de hastaları için daha konforlu bir tedavi planlaması yapmaları adına farkındalıklarının ve bilgi düzeylerini arttırmak amacıyla, verilen eğitimin müfredatlarında bu konuyla ilgili güncellemelerin yapılması önerilmektedir. 


\section{KAYNAKLAR}

1. Marx, R.E., Pamidronate (Aredia) and zoledronate (Zometa) induced avascular necrosis of the jaws: a growing epidemic. J Oral Maxillofac Surg, 2003. 61(9): p. 1115-7.

2. Ruggiero, S.L., B. Mehrotra, T.J. Rosenberg, S.L.J.J.o.o. Engroff, and m. surgery, Osteonecrosis of the jaws associated with the use of bisphosphonates: a review of 63 cases. 2004. 62(5): p. 527-534.

3. Rosella, D., P. Papi, G. Pompa, M. Capogreco, F. De Angelis, and S.J.E.j.o.d. Di Carlo, Dental students' knowledge of medication-related osteonecrosis of the jaw. 2017. 11(4): p. 461.

4. Escobedo, M., L. García-Consuegra, S. Junquera, S. Olay, G. Ascani, L.J.J.o.s. Junquera, oral, et al., Medication-related osteonecrosis of the jaw: A survey of knowledge, attitudes, and practices among dentists in the principality of Asturias (Spain). 2018. 119(5): p. 395-400.

5. Ruggiero, S.L., T.B. Dodson, L.A. Assael, R. Landesberg, R.E. Marx, B.J.J.o.O. Mehrotra, et al., American Association of Oral and Maxillofacial Surgeons position paper on bisphosphonate-related osteonecrosis of the jaws-2009 update. 2009. 67(5): p. 2-12.

6. Kolarov, R., D. Rachev, D. Dobrev, and B.J.M. Toncheva, Medication-related osteonecrosis of the jaws-a retrospective study. 2017. 4(2): p. 632-640.

7. Hamadeh, I.S., B.A. Ngwa, and Y.J.C.t.r. Gong, Drug induced osteonecrosis of the jaw. 2015. 41(5): p. 455464.

8. Pickett, F.A., Update on Medication Related Osteonecrosis of the Jaw. 2015.

9. Escobedo, M.-F., L. García-Consuegra, S. Gay, L. Álvarez, S. Olay, G. Ascani, et al., Influence of the teaching program on the learning in knowledge and practice of osteonecrosis of the jaws produced by antireasorptives in dental students of the Principality of Asturias (Spain). 2017. 9(12): p. e1402.

10.Kim, J.-W., S.-R. Jeong, S.-J. Kim, and Y.J.B.o.h. Kim, Perceptions of medical doctors on bisphosphonaterelated osteonecrosis of the jaw. 2016. 16(1): p. 92.

11.Aksoy, M.Ç., G. Koçer, M. Koçer, and T.J.I.J.C.E.M. Baykul, Medication related osteonecrosis of the jaws: a case serial study. 2017. 10(11): p. 15672-15679.

12.Ruggiero, S.L., T.B. Dodson, J. Fantasia, R. Goodday, T. Aghaloo, B. Mehrotra, et al., American Association of Oral and Maxillofacial Surgeons position paper on medication-related osteonecrosis of the jaw-2014 update. 2014. 72(10): p. 1938-1956.

13.Rahman, Z., S. Nayani, H. Anstey, and M.J.O.S. Murphy, A survey evaluating the awareness of MRONJ within the Birmingham GMP community. 2018.

14. Tanna, N., C. Steel, S. Stagnell, and E. Bailey, Awareness of medication related osteonecrosis of the jaws (MRONJ) amongst general dental practitioners. $\mathrm{Br}$ Dent J, 2017. 222(2): p. 121-125.
15.López-Jornet, P., F. Camacho-Alonso, F. MolinaMiñano, and F.J.J.o.e.i.c.p. Gomez-Garcia, Bisphosphonate-associated osteonecrosis of the jaw. Knowledge and attitudes of dentists and dental students: a preliminary study. 2010. 16(5): p. 878-882.

16.16. Khosla, S., D. Burr, J. Cauley, D.W. Dempster, P.R. Ebeling, D. Felsenberg, et al., Bisphosphonate-associated osteonecrosis of the jaw: report of a task force of the American Society for Bone and Mineral Research. Journal of bone and mineral research, 2007. 22(10): p. 1479-1491.

17.17. Edwards, B.J., M. Gounder, J.M. McKoy, I. Boyd, M. Farrugia, C. Migliorati, et al., Pharmacovigilance and reporting oversight in US FDA fast-track process: bisphosphonates and osteonecrosis of the jaw. The lancet oncology, 2008. 9(12): p. 1166-1172.

18.18. Ahmadov, R., F. Karacaoğlu, and M. Akkaya, Diş Hekimlerinin Bifosfonatlar ve Bifosfonat İlişkili Çene Nekrozu Hakkında Bilgi, Düşünce ve Davranışlarının Değerlendirilmesi. Turkiye Klinikleri. Dishekimligi Bilimleri Dergisi, 2018. 24(2): p. 114-122.

19.19. Vandone, A., M. Donadio, M. Mozzati, M. Ardine, M. Polimeni, S. Beatrice, et al., Impact of dental care in the prevention of bisphosphonateassociated osteonecrosis of the jaw: a singlecenter clinical experience. Annals of Oncology, 2011. 23(1): p. 193-200.

20.20. Lo, J.C., F.S. O'Ryan, N.P. Gordon, J. Yang, R.L. Hui, D. Martin, et al., Prevalence of osteonecrosis of the jaw in patients with oral bisphosphonate exposure. Journal of Oral and Maxillofacial Surgery, 2010. 68(2): p. 243-253.

21.21. McGowan, K., S. Ivanovski, and C.J.A.d.j. Acton, Osteonecrosis of the jaws: a 14-year retrospective survey of hospital admissions. 2018. 63(2): p. 202-207.

22.22. Reid, I.R., Osteonecrosis of the jaw - who gets it, and why? Bone, 2009. 44(1): p. 4-10.

Yazışma Adresi:

Ahmet Faruk ERTÜRK

İstanbul Üniversitesi

Diş Hekimliği Fakültesi

Ağız, Diş ve Çene Radyolojisi AD.

İstanbul, Türkiye

E Posta: afebty@gmail.com 